University of Nebraska - Lincoln

DigitalCommons@University of Nebraska - Lincoln

\title{
Identification of wild apple germplasm (Malus spp.) accessions with resistance to the postharvest decay pathogens Penicillium expansum and Colletotrichum acutatum
}

\author{
W. M. Jurick II \\ USDA-ARS, Wayne.Jurick@ars.usda.gov \\ W. J. Janisiewicz \\ USDA-ARS \\ R. A. Saftner \\ USDA-ARS \\ I. Vico \\ USDA-ARS \\ V. L. Gaskins \\ USDA-ARS \\ See next page for additional authors \\ Follow this and additional works at: https://digitalcommons.unl.edu/usdaarsfacpub \\ Part of the Agricultural Science Commons
}

Jurick, W. M. Il; Janisiewicz, W. J.; Saftner, R. A.; Vico, I.; Gaskins, V. L.; Park, E.; Forsline, P. L.; Fazio, G.; and Conway, W. S., "Identification of wild apple germplasm (Malus spp.) accessions with resistance to the postharvest decay pathogens Penicillium expansum and Colletotrichum acutatum" (2011). Publications from USDA-ARS / UNL Faculty. 564.

https://digitalcommons.unl.edu/usdaarsfacpub/564

This Article is brought to you for free and open access by the U.S. Department of Agriculture: Agricultural Research Service, Lincoln, Nebraska at DigitalCommons@University of Nebraska - Lincoln. It has been accepted for inclusion in Publications from USDA-ARS / UNL Faculty by an authorized administrator of DigitalCommons@University of Nebraska - Lincoln. 


\section{Authors}

W. M. Jurick II, W. J. Janisiewicz, R. A. Saftner, I. Vico, V. L. Gaskins, E. Park, P. L. Forsline, G. Fazio, and W. S. Conway 


\section{Identification of wild apple germplasm (Malus spp.) accessions with resistance to the postharvest decay pathogens Penicillium expansum and Colletotrichum acutatum}

W. M. Jurick II ${ }^{1,4}$, W. J. Janisiewicz ${ }^{2}$, R. A. Saftner ${ }^{1}$, I. Vico ${ }^{1}$, V. L. Gaskins ${ }^{1}$, E. Park ${ }^{1}$, P. L. Forsline ${ }^{3}$, G. FAZIO ${ }^{3}$ and W. S. Conway ${ }^{1}$

${ }^{1}$ USDA-ARS, Food Quality Laboratory, 10300 Baltimore Ave, Beltsville, MD 20705, USA; ${ }^{2}$ USDA-ARS, Appalachian Fruit Research Station, 2217 Wiltshire Rd, Kerneysville, WV 25430, USA; ${ }^{3}$ USDA-ARS, Plant Genetic Resources Unit, 630 West North Street, Geneva, NY 14456, USA; ${ }^{4}$ Corresponding author e-mail: Wayne.Jurick@ars.usda.gov

With 3 figures and 4 tables

Received June 3, 2010/Accepted December 21, 2010

Communicated by F. Ordon

\begin{abstract}
Penicillium expansum and Colletotrichum acutatum cause blue mould and bitter rot of apples during storage which results in significant economic losses. Resistance to these pathogens in commercial apple cultivars has not been documented in the literature. An apple germplasm collection, from the centre of origin in Kazakhstan, is maintained in Geneva, New York. This collection represents a more diverse apple gene pool than commercial cultivars and was evaluated for resistance to the pathogens that cause blue mould and bitter rot. Resistance reactions were skewed towards susceptibility for both fungi and comprised the majority of accessions examined. However, resistance to $P$. expansum was confirmed in select accessions over multiple years. Maturation patterns and quality indices for soluble solids and acidity, which may also affect susceptibility, were highly variable and represent the genetic diversity of the germplasm collection. Resistance in four accessions to C. acutatum and two accessions resistant to both $P$. expansum and $C$. acutatum are reported here for the first time. Data from this study will serve as a foundation for conventional apple breeding programmes and molecular genetics investigations to provide resistance against blue mould and bitter rot in commercial apple varieties.
\end{abstract}

Key words: blue mould — bitter rot — wild apple germplasm

Domesticated apples (Malus $\times$ domestica Borkh.) are the fourth most important fruit crop in the world following citrus, grapes and bananas (Janick 2003). They are consumed worldwide and touted as 'health' food because of their high levels of antioxidants and phenolics (i.e. quercetin, catechin, phloridizin and chlorogenic acid) (Boyer and Liu 2004). Numerous studies have correlated the consumption of apples with a reduced risk for some cancers, heart disease, asthma and diabetes (Boyer and Liu 2004). The genus Malus is composed of $\sim 27$ wild species of which Malus sieversii Lebed. has been identified as the distant ancestor of the domesticated apple (Ponomarenko 1987, 1992, Way et al. 1990, Morgan and Richards 1993, and Juniper et al. 1999). Samples from wild forest stands of $M$. sieversii located in Kazakhstan were collected in the 1990s by USDA scientists, which resulted in the 'Kazakh' collection of apple germplasm seedlings and clones (Forsline et al. 2003). This collection is located at the USDA/ARS Plant Genetic Resources Unit on the campus of Cornell's New York Agricultural Research station in Geneva, New York, and represents a wide variety of horticultural traits (i.e. forms, colours and tastes) and polymorphisms.
Economic losses because of postharvest decay of apples have been estimated to exceed $\$ 4.4$ million per year in the United States (Rosenberger 1997). Blue mould of apples caused by Penicillium expansum was found during multiyear market surveys to be the most damaging postharvest pathogen (Cappellini et al. 1987). Penicillium expansum modulates its host environment through the production of organic acids to lower ambient $\mathrm{pH}$ which provides the optimal environment for cell wall degrading enzymes (i.e. polygalacturonase) to operate (Yao et al. 1996 and Prusky et al. 2004). Bitter rot, caused by Colletotrichum acutatum, is also an important apple pathogen that occurs both pre- and postharvest in the mid-Atlantic and southern United States (Biggs and Miller 2001). This disease is especially problematic in the field during hot and humid conditions and may result in $50-80 \%$ losses in unsprayed orchards (Camilo et al. 1988, Jones and Aldwinckle 1991). Colletotrichum acutatum is capable of latent infection which occurs during storage and also results in significant economic losses (Struble and Keitt 1950, Barkai-Golan 2001). Virulence mechanisms of C. acutatum involve ammonia production to increase host tissue $\mathrm{pH}$ while concomitantly facilitating optimal activity of pectate lyase (Prusky et al. 2001).

There are reports detailing the lack of resistance to both blue mould and bitter rot in commercial varieties (Cappellini et al. 1987, Spotts et al. 1999, Biggs and Miller 2001, and Janisiewicz and Peterson 2004). Therefore, it is possible that through intense cultivation and breeding, the gene or genes for resistance to postharvest decay pathogens were lost via a genetic bottleneck. However, a recent study detailing the preliminary evaluation of the wild apple germplasm from the 'Kazakh' collection in Geneva, NY, showed that it contains accessions with resistance to blue mould (Janisiewicz et al. 2008). Therefore, the objectives of this study were to: (i) examine the distribution of resistance to both $P$. expansum and C. acutuatum from the Kazakh germplasm collection on a large scale over multiple years, (ii) focus on identification of accessions with resistance to both pathogens, and (iii) determine if overlapping resistance occurs to these decay pathogens in wild apple species.

\section{Materials and Methods}

Fruit: Apples were harvested from Elite trees (clonally propagated from budwood collected in Kazakhstan) which were identified by PI 
number and from seedling trees (grown from seeds collected from elite trees in open pollinated forests in Kazakhstan). Trees were identified with the GMAL number and letter extension for individual seeds of fruit from an elite accession. Details of orchard lay out and tree spacing have been detailed previously by Janisiewicz et al. (2008). Investigations for resistance included other wild Malus species from areas of Eastern Europe like Macedonia where accession PI 369855 was collected and from the Caucasus of the former Soviet Union where accession GMAL 4487.i was obtained. For all accessions, the harvest dates were established based on bloom time, visual observations from multiyear data and starch accumulation patterns. Approximately 120 fruit were harvested from each accession and were used for pathogen inoculations and maturity-related evaluations. Fruit were placed in labelled bags and kept in cardboard boxes at $20^{\circ} \mathrm{C}$ overnight. The following morning they were transported to the Agricultural Research Center in Beltsville, MD, and to the Appalachian Fruit Research Station in Kearneysville, WV.

Estimation of fruit maturity for harvest: Preceding each harvest, five fruit were tested from each accession to estimate maturity using the iodine starch test on a 1-9 point scale developed for 'Golden Delicious' apple fruit (Smith et al. 1979). Fruit were selected for harvest with starch values $>3$ but $<6$. However, in a limited number of cases, some accessions were harvested with starch scores as low as 2.5 and as high as nine because of disparities between starch patterns and fruit maturity which have previously been documented by Janisiewicz et al. (2008).

Determination of fruit maturity and quality indicators: For each accession, $\mathrm{CO}_{2}$ and ethylene production from a 5 to 12 fruit sample ( 200-300 g) were measured every $6 \mathrm{~h}$ during a 7 -day period at $20^{\circ} \mathrm{C}$ using an automated flow-through system (Izumi et al. 1996, Janisiewicz et al. 2008). Apple accessions were categorized into five maturity stages: preclimacteric, preclimacteric/climacteric, climacteric, climacteric/postclimacteric and postclimacteric. These categories were based on relative amounts and changes in patterns observed for both ethylene and $\mathrm{CO}_{2}$ evolution during the time between pathogen inoculation and decay evaluations. Soluble solids content and titratable acidity were measured on juice extracts from 3 to 10 fruit of each accession. Fruit samples were macerated in an electric blender and the juice separated from the pulp by squeezing through two layers of cheesecloth. Soluble solids content of the juice samples were measured using a digital, temperature compensated refractometer (model PR-101; Atago Co,. Habashi-Ku, Tokyo, Japan). Titratable acidity for each accession was determined by titrating $10 \mathrm{ml}$ of juice sample with $1.0 \mathrm{M} \mathrm{KOH}$ to $\mathrm{pH} 8.2$ and expressed as \% malic acid (Mitcham and Kader 1996).

Pathogens: Penicillium expansum (MD-8) and Colletorichum acutatum (CA-1) isolates were isolated from decayed apples. Both fungi were cultured on potato dextrose agar (PDA). Aqueous conidial suspensions were prepared as previously described by Janisiewicz et al. (2008).

Fruit inoculation: For each pathogen and conidial concentration, 20 apples per accession were placed in a fruit tray and wounded at the equator to a depth of $3 \mathrm{~mm}$ with a 6-penny nail. Each wound was inoculated with $50 \mu \mathrm{l}$ of conidial suspension $\left(1 \times 10^{3}\right.$ or $1 \times 10^{4}$ per ml $)$ of either P.expansum or C. acutatum. The inoculated fruit were incubated at $22^{\circ} \mathrm{C}$ for 5 days for $P$. expansum and 6 days for C. acutatum and then evaluated for decay development by assessing incidence and severity (lesion diameter) of decay. A total of 452 accessions were inoculated with $P$. expansum (148 in 2007, 186 in 2008, and 118 in 2009) and were evaluated for decay. A total of 271 accessions were inoculated with C. acutatum (175 in 2008 and 96 in 2009) and were also evaluated for decay. Decay evaluations for both pathogens were evaluated on 163 accessions in 2008 and 72 accessions in 2009. Based on incidence of decay, the accessions were divided into (a)

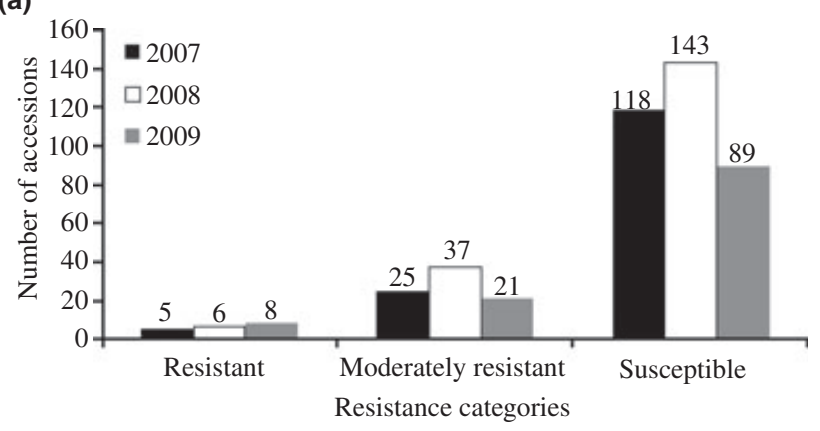

(b)

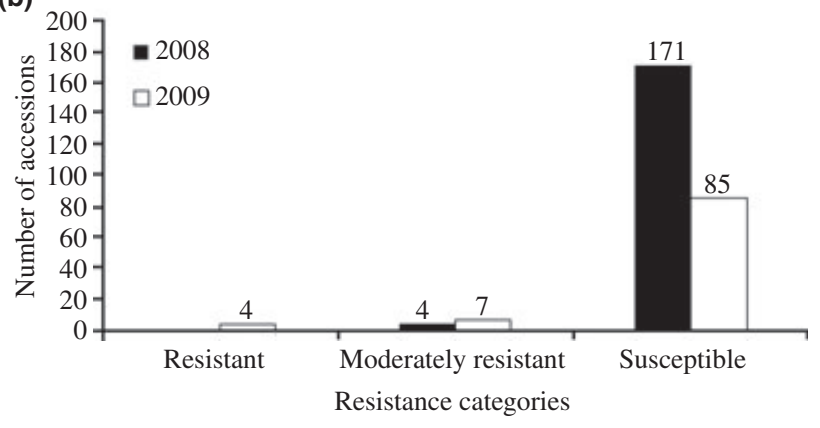

Fig. 1: Distribution of resistance categories from wild apple accessions with various levels of resistance against (a) Penicillium expansum and (b) Colletotrichum acutatum

three categories: resistant $=$ no decay at $1 \times 10^{3}$ and $1 \times 10^{4}$ per ml, moderately resistant $=$ no decay at $1 \times 10^{3}$ per $\mathrm{ml}$, and susceptible $=$ decay evident at both $1 \times 10^{3}$ and $1 \times 10^{4}$ per $\mathrm{ml}$.

Weather data: Weather data were obtained from the New York State Agricultural Experiment Station for temperature and rainfall and mean monthly values were calculated (Kazakh apple bloom to harvest) from April to October 2007-2009.

\section{Results}

From 2007 to 2009, a total of 452 accessions were evaluated for maturity, quality indices and blue mould development incited by $P$. expansum. The distribution of reactions was skewed towards susceptibility (i.e. decay evident at conidial concentrations of $10^{3}$ and $10^{4}$ per $\mathrm{ml}$ ) for each year and 350 of the 452 or $77.4 \%$ of the accessions tested were susceptible (Figs 1a and 3c). However, 18.3\% (83 accessions) were moderately resistant (no decay at $10^{3}$ per $\mathrm{ml}$ ) and $4.2 \%$ (19 accessions) were resistant (no decay at $10^{3}$ and $10^{4}$ per ml) (Fig. 1a). Accessions exhibiting resistance to $P$. expansum were all $M$. sieversii except GMAL 4487.i (M. orientalis) and PI 369855 (M. sylvestris) (Table 1 and Fig. 3b). Collection sites for wild apple accessions and their corresponding GPS coordinates are located in Table 1 and indicate that 11 accessions were collected from site 6, 2 accessions each from sites 9 and 11 and 1 accession each from sites 12 and 5. The resistant Kazakh accessions had soluble solids ranging from $7.3 \%$ to $20.1 \%$ and titratable acidity values ranging from $0.22 \%$ to $2.65 \%$ malic acid (Table 1 ). Fruit size among accessions ranged from 12.8 to 2.6 times smaller than the standard 100-count 'Golden Delicious' apple fruit (Table 1). Maturity, as determined via ethylene and $\mathrm{CO}_{2}$ production 
Table 1: Resistant accessions from the wild apple germplasm of elite (PI) and seedlings (GMAL) to Penicillium expansum ${ }^{1}$

\begin{tabular}{|c|c|c|c|c|c|c|c|c|}
\hline Accession & $\begin{array}{l}\text { Collection } \\
\text { site }^{2}\end{array}$ & $\begin{array}{l}\text { Latitude, } \\
\text { longitude }\end{array}$ & Year & Malus spp. & $\begin{array}{c}\text { Soluble } \\
\text { sugars (\%) }\end{array}$ & $\begin{array}{c}\text { Titratable } \\
\text { acidity }(\%)\end{array}$ & $\begin{array}{l}\text { Fruit } \\
\text { size }^{3}\end{array}$ & Estimated maturity \\
\hline GMAL 3635.i & 9 & $47.26,81.58$ & 2007 & sieversii & 9.7 & 0.2 & 6.2 & Climacteric/postclimacteric \\
\hline GMAL 3689.e & 6 & $42.89,69.88$ & 2007 & sieversii & 11.2 & 1.3 & 6.2 & Climacteric \\
\hline GMAL $3689 . i$ & 6 & $42.89,69.88$ & 2007 & sieversii & 8.6 & 1.2 & 10.5 & Climacteric \\
\hline GMAL 3689.p & 6 & $42.89,69.88$ & 2007 & sieversii & 10.2 & 1.5 & 10.5 & Climacteric \\
\hline PI 613981 & 6 & $42.89,69.88$ & 2007 & sieversii & 11.0 & 1.7 & 5.1 & Climacteric \\
\hline GMAL 3688.h & 6 & $42.89,69.88$ & 2008 & sieversii & 10.8 & 1.3 & 6.2 & Climacteric \\
\hline GMAL 3685.d & 6 & $42.89,69.88$ & 2008 & sieversii & 11.1 & 1.2 & 5.8 & Preclimacteric/Climacteric \\
\hline GMAL 4317.f & 12 & $42.33,70.37$ & 2008 & sieversii & 12.0 & 1.3 & 6.9 & Preclimacteric/Climacteric \\
\hline GMAL 3687.e & 6 & $42.89,69.88$ & 2008 & sieversii & 11.4 & 1.5 & 4.8 & Preclimacteric/Climacteric \\
\hline GMAL 3688.j & 6 & $42.89,69.88$ & 2008 & sieversii & 10.6 & 1.0 & 4.6 & Climacteric \\
\hline GMAL $3691 . j$ & 6 & $42.89,69.88$ & 2008 & sieversii & 12.6 & 0.2 & 5.6 & Preclimacteric/Climacteric \\
\hline GMAL 4487.i & -4 & $44.45,40.21$ & 2009 & orientalis & 8.6 & 2.6 & 12.8 & Climacteric \\
\hline GMAL 3684.a & 6 & $42.89,69.88$ & 2009 & sieversii & 9.6 & 0.6 & 3.7 & Climacteric/postclimacteric \\
\hline GMAL 3625.a & 9 & $47.26,81.57$ & 2009 & sieversii & 7.3 & 1.1 & 4.7 & Climacteric \\
\hline GMAL 4286.c & 11 & $42.70,70.27$ & 2009 & sieversii & nd & nd & nd & nd \\
\hline GMAL 4304.d & 11 & $42.66,70.25$ & 2009 & sieversii & 20.1 & 0.3 & 2.6 & Climacteric/postclimacteric \\
\hline GMAL 3547.n & 5 & $45.40,80.40$ & 2009 & sieversii & 10.5 & 1.5 & 5.1 & Preclimacteric \\
\hline PI 369855 & -5 & 6 & 2009 & sylvestris & 10.3 & 1.8 & 12.0 & Climacteric \\
\hline GMAL 3689.h & 6 & 42.89 .69 .88 & 2009 & sieversii & 11.6 & 1.4 & 5.0 & Preclimacteric/climacteric \\
\hline
\end{tabular}

${ }^{1}$ These 19 wild apple accessions were found to be resistant to $P$. expansum of the 452 evaluated.

${ }^{2}$ Information on specific collection sites can be found in Janick (2003) or online at http://www.ars-grin.gov/npgs/acc/acc_queries.html

${ }^{3}$ Data for fruit size is presented as fold smaller than a typical 100-count 'Golden Delicious' apple fruit.

${ }^{4}$ Seed collected on 26 July 1998 in the Caucasus of the Former Soviet Union.

${ }^{5}$ Specific collection site is unknown, but seed was collected in Macedonia in 1971.

${ }^{6}$ Longitude and latitude for specific collection site is not known.

nd, Not determined.

rates, during decay evaluations was also variable, but only one accession (GMAL 3547.n) was harvested and evaluated in the preclimacteric stage. Nine accessions were climacteric, five were going into the climacteric stage, and three were beginning to senesce during decay evaluation (Table 1).

Apples from Kazakh accessions harvested from 2008 to 2009 were also evaluated for maturity, quality indices and bitter rot caused by $C$. acutatum. The overall distribution of reactions to $C$. acutatum was skewed for susceptibility (Fig. 1b). Of 271 accessions, $4(1.4 \%)$ were resistant, 11 $(4.0 \%)$ moderately resistant and $256(94.4 \%)$ were susceptible to C. acutatum (Fig. 3d). Collection sites for wild apple accessions and their corresponding GPS coordinates are listed in Table 2 and indicate that 2 accessions were collected from site 6 and one from site 3 from Kazakhstan. There were three $M$. sieversii, one $M$. sylvestris species that were resistant and which had soluble solids ranging from $9.3 \%$ to $11.6 \%$ and titratable acidity from $1.0 \%$ to $1.8 \%$ malic acid (Table 2 ). Fruit size among the accessions varied from 12.0 to 4.5 times smaller than 100-count 'Golden Delicious' apple fruit (Table 2). Fruit maturity, as measured via ethylene and $\mathrm{CO}_{2}$ production rates, indicated that three accessions were going into the climacteric state and one was deemed climacteric during decay analysis (Table 2).

Resistance to P. expansum was examined over a two- or three-year period (2007-2009) for accessions that initially showed no decay (resistant). One of the six accessions tested (GMAL 3688.h) performed consistently during 2008 and 2009 with no decay at either concentration (Table 3). Repeat analysis of accessions GMAL 3547.n and GMAL 3625.a had no decay evident at a conidial concentration of $10^{3}$ per $\mathrm{ml}$. However, low incidence was observed at $10^{4}$ per $\mathrm{ml}$ for both accessions and GMAL 3547.n specifically had only a single lesion (5\% decay incidence). Accessions GMAL 3635.i, GMAL 3689.i and GMAL 3689.p performed in a similar manner from year to year as they had lower incidence and severity of decay at $10^{3}$ vs. $10^{4}$ per $\mathrm{ml}$.

Average temperatures for all 3 years revealed similar trends from April to October 2007 through 2009. April and October had the lowest mean temperatures and July consistently had the highest (Fig. 2a). However, rainfall patterns did vary from year to year with 2008 and 2009 having similar patterns. Mean rainfall for June through August 2007 was lower for the same time frame than in 2008 and 2009 (Fig. 2b).

A total of six accessions had overlapping levels of resistance to both bitter rot and blue mould in 2008 and 2009. Two accessions evaluated in 2009 (PI 369855, M. sylvestris and GMAL 3689.h, M. sieversii) were resistant to both $P$. expansum and C. acutatum (Table 4, Fig. 3a,b). One accession harvested in 2009 (GMAL 3625.a) was resistant to P. expansum and moderately resistant to C. acutatum. However, the bulk of overlap occurred in 2009, where four accessions were moderately resistant to both pathogens (Table 4). The remaining fruit that were inoculated with both pathogens in 2008 were susceptible except 35 accessions. Two of the exceptions included were moderately resistant to C. acutatum and susceptible to $P$. expansum, and 33 were resistant or moderately resistant to $P$. expansum but susceptible to $C$. acutatum. Accessions inoculated in 2009 with both fungi were mostly susceptible. However, six were resistant or moderately resistant to $P$. expansum and were also susceptible to $C$. acutatum. Conversely, three accessions were resistant or moderately resistant to $C$. acutatum and susceptible to $P$. expansum.

\section{Discussion}

Results from this study have demonstrated resistance against $P$. expansum or C. acutatum in apple fruit from select wild apple fruit accessions. Resistance against both pathogens has not been identified in domesticated apples (Spotts et al. 1999 

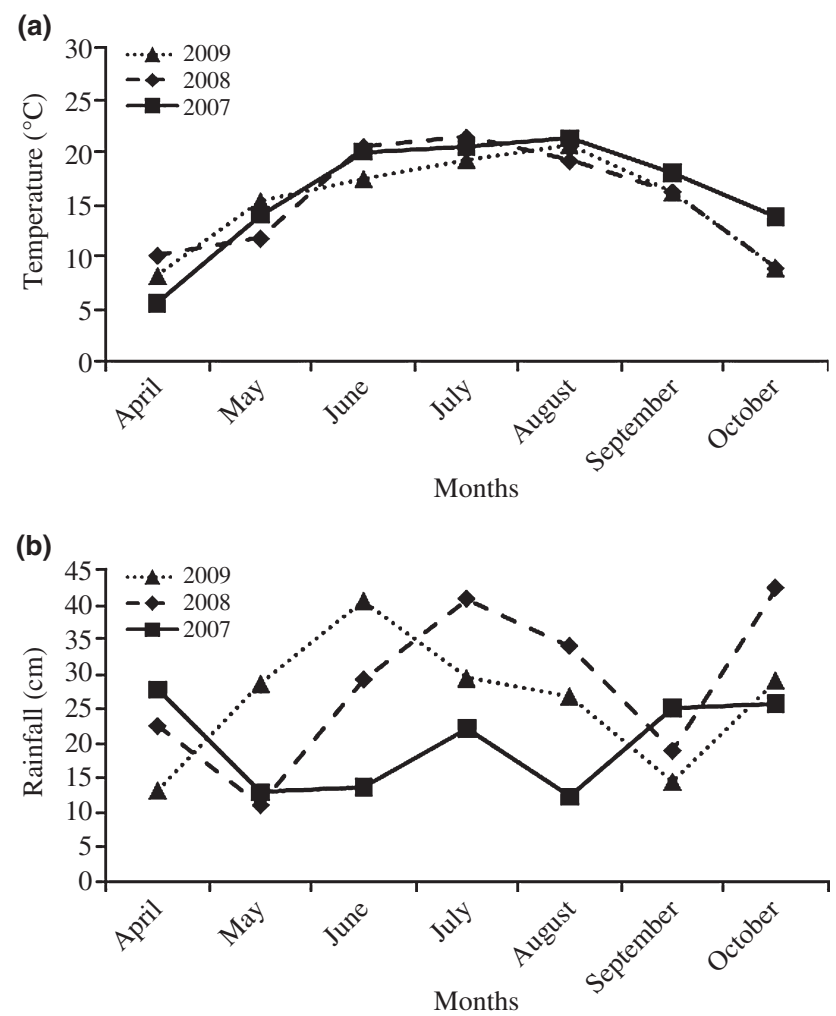

Fig. 2: Weather data from the New York State Agricultural Experiment Station located in Geneva, New York. (a) Mean monthly temperatures from April through October 2007-2009. (b) Mean monthly rainfall from April through October 2007-2009

and Biggs and Miller 2001) and also has not been reported for other wild apple species. Distribution of reactions against blue mould (2007-2009) and bitter rot (2008-2009) was skewed towards susceptibility (Fig. 1a,b). The tendency of wild apple fruit for susceptibility to postharvest pathogens may be because of the lack of selection pressure for resistance to fruit decay which may enhance seed propagation. Under favourable conditions that occur in mountain regions, renewal by seed is minimal and accounts for only $10-15 \%$ of the total amount of apple stand growth. The majority of wild apple stands spread vegetatively (Dzhangaliev 2003).

Variability in maturity patterns, levels of soluble solids and titratable acidity, fruit size and differences in resistance levels to blue mould and bitter rot confirm the diversity that is represented in the Kazakh collection (Dzhangaliev 2003). Apples are a climacteric fruit that undergo changes in ethylene and $\mathrm{CO}_{2}$ production, texture, skin colour, acidity, cuticular waxes and aromatic compounds (Kidd and West 1924, Knee
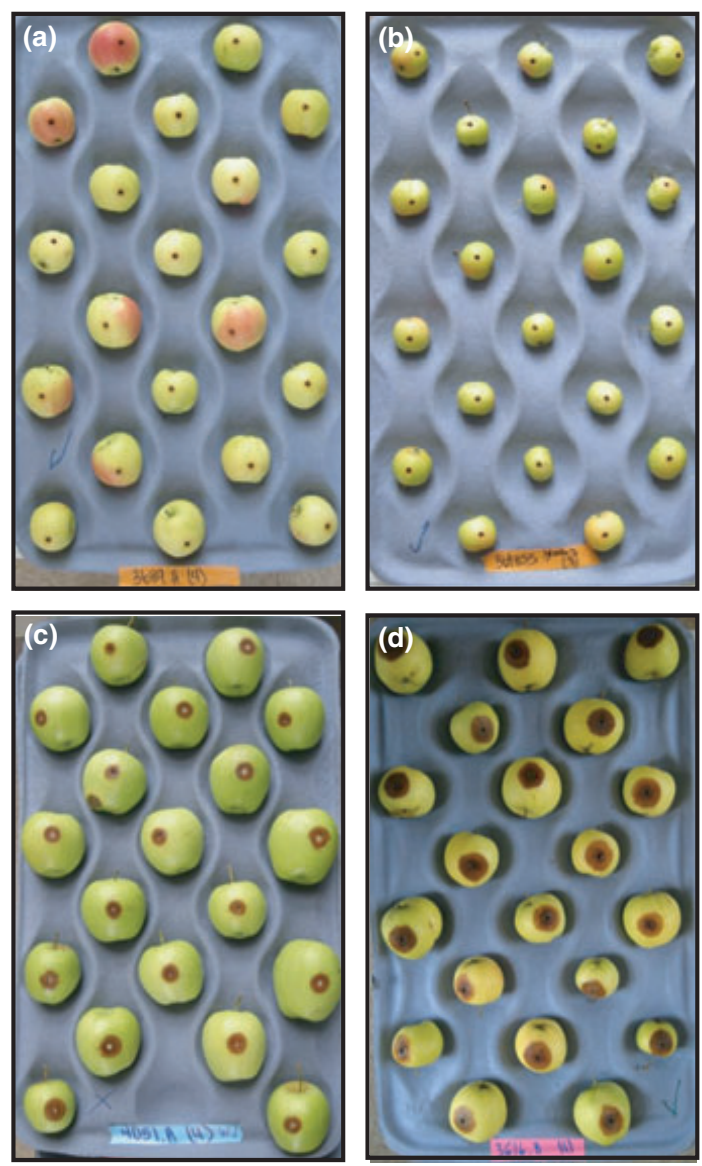

Fig. 3: Bitter rot and blue mould decay development on (a) GMAL 3689.h inoculated with $50 \mu \mathrm{l}$ of $10^{4}$ per $\mathrm{ml}$ conidial suspension of Colletotrichum acutatum (resistant) is also resistant to Penicillium expansum. (b) PI 369855 inoculated with $50 \mu \mathrm{l}$ of $10^{3}$ per $\mathrm{ml}$ conidial suspension of C. acutatum (resistant) is also resistant to P. expansum. (c) GMAL 4051.a inoculated with $10^{4}$ per $\mathrm{ml}$ conidial suspension of P. expansum (susceptible). (d) GMAL 3616.b inoculated with $10^{4}$ per $\mathrm{ml}$ conidial suspension of C. acutatum (susceptible)

1993). Many environmental factors (e.g. temperature, water stress, light, etc.) impact the maturity, quality and resistance of apple fruit. To effectively evaluate the resistance level of each accession, we avoided testing fruit in the preclimacteric stage. Only one of the 19 accessions that was resistant to P. expansum was determined to have remained in the preclimacteric stage of development during decay evaluation and was likely harvested immature (Table 1). Therefore, this accession should be re-evaluated to determine if the resistance was the result of the maturity of the fruit or because of genetic factor(s) maintaining resistance. Fruit from all other resistant

Table 2: Resistant accessions from the wild apple germplasm collection of elite (PI) and seedling (GMAL) apples to Colletotrichum acutatum

\begin{tabular}{|c|c|c|c|c|c|c|c|c|}
\hline Accession & $\begin{array}{l}\text { Collection } \\
\text { site }\end{array}$ & $\begin{array}{l}\text { Latitude, } \\
\text { longitude }\end{array}$ & Year & Malus spp. & $\begin{array}{c}\text { Soluble } \\
\text { sugars }(\%)\end{array}$ & $\begin{array}{c}\text { Titratable } \\
\text { acidity }(\%)\end{array}$ & $\begin{array}{l}\text { Fruit } \\
\text { size }^{1}\end{array}$ & Estimated maturity \\
\hline PI 369855 & $-^{2}$ & -3 & 2009 & sylvestris & 10.3 & 1.8 & 12.0 & Climacteric \\
\hline GMAL 3689.h & 6 & $42.89,69.88$ & 2009 & sieversii & 11.6 & 1.4 & 5.0 & Preclimacteric/climacteric \\
\hline GMAL 3709.c & 3 & $43.12,76.80$ & 2009 & sieversii & 10.3 & 1.0 & 4.5 & Preclimacteric/climacteric \\
\hline GMAL 3690.1 & 6 & $42.89,69.88$ & 2009 & sieversii & 9.3 & 1.2 & 5.8 & Preclimacteric/climacteric \\
\hline
\end{tabular}

${ }^{1}$ Data for fruit size is presented as fold smaller than a typical 100-count 'Golden Delicious' apple fruit.

${ }^{2}$ Specific collection site is unknown, but seed was collected in Macedonia in 1971.

${ }^{3}$ Longitude and latitude for specific collection site is not known. 
Table 3: Multiple year comparisons of Penicillium expansum-resistant apple accessions from wild apple collection

\begin{tabular}{|c|c|c|c|c|c|c|c|c|c|c|c|c|}
\hline \multirow[b]{3}{*}{ Accession } & \multicolumn{4}{|c|}{2007} & \multicolumn{4}{|c|}{2008} & \multicolumn{4}{|c|}{2009} \\
\hline & \multicolumn{2}{|c|}{$\begin{array}{c}\text { Incidence } \\
(\%)\end{array}$} & \multicolumn{2}{|c|}{$\begin{array}{l}\text { Lesion size } \\
\quad(\mathrm{mm})\end{array}$} & \multicolumn{2}{|c|}{$\begin{array}{c}\text { Incidence } \\
(\%)\end{array}$} & \multicolumn{2}{|c|}{ Lesion size (mm) } & \multicolumn{2}{|c|}{$\begin{array}{c}\text { Incidence } \\
(\%)\end{array}$} & \multicolumn{2}{|c|}{ Lesion size $(\mathrm{mm})$} \\
\hline & $10^{31}$ & $10^{4}$ & $10^{3}$ & $10^{4}$ & $10^{3}$ & $10^{4}$ & $10^{3}$ & $10^{4}$ & $10^{3}$ & $10^{4}$ & $10^{3}$ & $10^{4}$ \\
\hline GMAL 3635.i & 0 & 0 & 0 & 0 & 5 & 15 & $0.1(1.3)$ & $0.3(2.6)$ & 0 & 85 & 0 & $8.5(4.4)$ \\
\hline GMAL $3689 . \mathrm{i}$ & 0 & 0 & 0 & 0 & nd & nd & nd & nd & 5 & 60 & $0.3(1.3)$ & $4.8(4.1)$ \\
\hline GMAL 3689.p & 0 & 0 & 0 & 0 & nd & nd & nd & nd & 25 & 70 & $0.3(0.6)$ & $2.0(2.4)$ \\
\hline GMAL 3688.h & nd & nd & nd & nd & 0 & 0 & 0 & 0 & 0 & 0 & 0 & 0 \\
\hline GMAL $3625 . \mathrm{a}$ & 0 & 20 & nd & nd & nd & nd & nd & nd & 0 & 0 & 0 & 0 \\
\hline GMAL 3547.n & nd & nd & nd & nd & 0 & 5 & 0 & $0.1(1.5)$ & 0 & 0 & 0 & 0 \\
\hline
\end{tabular}

${ }^{1}$ Conidial suspensions of Penicillium expansum are indicated as concentrations of either $10^{3}$ or $10^{4}$ per ml.

Mean values for incidence and lesion size are indicated, and standard deviation is shown in parenthesis.

nd, Not determined.

accessions were evaluated during decay at the climacteric stage of development, i.e. were mature ripening fruit, which indicates that maturity was not a major factor affecting disease resistance in these accessions. Accessions which exhibited resistance in the climacteric or postclimacteric stage are excellent candidates for future studies as their resistance is more likely because of genetic than maturity factors. Additional evidence which suggests that resistance to postharvest pathogens involves a genetic component may be supported by the observation that $\sim 57.8 \%$ of the resistant accessions was collected from a single site (\#6) in Kazakhstan. Site numbers 6, 11,12 are approximately $40 \mathrm{~km}$ from each other and together account for $\sim 73.6 \%$ of the resistant accessions that were analysed. This observation may also be useful in targeting specific additional accessions from the Kazakh collection for resistance to postharvest pathogens as this trait seems to be clustered in a specific geographical area.

Analysis of resistant accessions over multiple years was conducted in this study to determine the 'durability' of resistance under varying environmental conditions from 2007 to 2009 for blue mould. However, not all resistant accessions were retested because of the presence of strong biennial fruiting which has been previously demonstrated for the Kazakh collection (Janisiewicz et al. 2008). Of the multitude of environmental factors that may account for the variability in resistant accessions (temperature, drought and nutrition), it appears that varying amounts of rainfall may be responsible for exerting differential effects on apple fruit resistance. In 2008 and 2009, the level of rainfall was higher than in 2007, early in the season during flowering and fruit development (Fig. 3b). Evidence for early water stress impacting susceptibility to bitter pit, corking disorders and insect reductions has been previously demon- strated (Sharples 1973, Goode 1975, Lotter et al. 1985, Fransesconi et al. 1996). Therefore, higher precipitation levels in 2008 and 2009 may have impacted disease resistance in four of the six accessions that were re-evaluated during those years. However, not all accessions responded in a similar manner during 2008 and 2009, which suggests that other environmental and/or genetic factors may be either enhancing or reducing the overall resistance levels in wild apple fruit.

We tested $P$. expansum-resistant accessions against $C$. acutatum to determine the specificity of resistance to another economically important apple fruit pathogen. Results from this study showed that in most cases, if an accession was resistant to blue mould, it was susceptible to bitter rot and vice versa. However, resistance to both $P$. expansum and $C$. acutatum occurred in six accessions evaluated from the Kazakh apple germplasm collection. Two of the six accessions tested were resistant to both pathogens, one was resistant to $P$. expansum and moderately resistant to $C$. acutatum, and the remaining three were moderately resistant to both pathogens (Table 4). Different virulence mechanisms for these two fungal plant pathogens ( $P$. expansum and $C$. acutatum) has been previously demonstrated and may explain why overlap for resistance was limited (Prusky et al. 2001, 2004). Both of these fungal pathogens have distinct mechanisms for modulating the host environment to facilitate decay and increase virulence. Penicillium expansum causes host acidification through production of gluconic and citric acids in the host tissue, thereby lowering the $\mathrm{pH}$ for optimal production of polygalacturonase (Prusky et al. 2004). In contrast, the bitter rot pathogen, C. acutatum, secretes ammonia to increase host $\mathrm{pH}$ that favours pectate lyase enzyme production (Prusky et al. 2001). A possible explanation for the observed resistance

Table 4: Wild apple accessions with resistance to both Penicillium expansum and Colletotrichum acutatum

\begin{tabular}{lccc}
\hline Accession & Species & P. expansum & C. acutatum \\
\hline PI 369855 & sylvestris & Resistant & Resistant \\
GMAL 3689.h & sieversii & Resistant & Resistant \\
GMAL 3625.a & Resistant & Moderately resistant ${ }^{2}$ \\
GMAL 3999.a & sieversii & Moderately resistant & Moderately resistant \\
GMAL 3683.g & sieversii & Moderately resistant & Moderately resistant \\
GMAL 3684.1 & sieversii & Moderately resistant & Moderately resistant
\end{tabular}

\footnotetext{
${ }^{1}$ Resistant is defined as no decay when inoculated with a conidial suspension of $10^{3}$ and $10^{4}$ per ml.

${ }^{2}$ Moderately resistant is defined as no decay when inoculated with a conidial suspension of $10^{3}$ per $\mathrm{ml}$, and decay evident at $10^{4}$ per ml.
} 
to both pathogens may be because of increased accumulation of preformed defence compounds (i.e. benzoic acid) in apple fruit which have been shown to coincide with resistance to decay caused by Nectria galligena (Seng et al. 1985). However, we cannot rule out other preformed or induced resistance mechanisms in the Kazakh apple accessions which are interesting topics to pursue for future study.

Data from this study for the first time document resistance to both bitter rot and blue mould within specific accessions of the Kazakh apple germplasm collection located in Geneva, NY. This information will be useful to apple breeders in selecting accessions with resistance to one or both pathogens to use in crossing with commercial cultivars to obtain decayresistant breeding lines.

\section{Acknowledgements}

This work was supported by USDA project no. 1275-42430-008-00D and CGC grant awarded to W.J. Janisiewicz. We thank Nadine Gutkin for measuring starch values and Rodger Lewis for help with summarizing decay data. Mention of trade names or commercial products in the publication is solely for the purpose of providing specific information and does not imply recommendation or endorsement by the U.S. Department of Agriculture.

\section{References}

Barkai-Golan, R., 2001: Post harvest disease summary. In: Postharvest Diseases of Fruits and Vegetables, Development and Control, 291-310. Elsevier Science, Amsterdam, The Netherlands.

Biggs, A. R., and S. S. Miller, 2001: Relative susceptibility of selected apple cultivars to Colletotrichum acutatum. Plant Dis. 85, 657-660.

Boyer, J., and R. H. Liu, 2004: Apple photochemical and their health benefits. Nutr. J. 3, 5. doi:10.1186/1475-2891-3-5.

Camilo, A. P., R. C. Lamb, and H. S. Aldwinckle, 1988: Genetic resistance to bitter rot incited by Glomerella cingulata (Stoneman.) Spaulding and Schrenk in apple (Malus domestica (Borkh.)). Acta Hort. 232, 37-45.

Cappellini, R. A., M. J. Ceponis, and G. Lightner, 1987: Disorders in apple and pear shipments to the New York market, 1972-1984. Plant Dis. 71, 852-856.

Dzhangaliev, A. D., 2003: The wild apple tree of Kazakhstan. Hort. Rev. (Amer. Soc. Hort. Sci.) 29, 263-303.

Forsline, P. F., H. S. Aldwinckle, E. E. Dickson, J. J. Luby, and S. Hokanson, 2003: Collection, maintenance, characterization, and utilization of wild apples of central Asia. Hort. Rev. (Amer. Soc. Hort. Sci.) 29, $1-61$.

Fransesconi, A. H. D., A. N. Lakso, C. B. Watkins, J. P. Nyrop, J. Barnard, and S. Denning, 1996: Interactions of European red mite and crop load on maturity and quality, mineral concentrations, and economic value of 'Starkrimson Delicious' apples. J. Amer. Soc. Hort. Sci. 121, 967-972.

Goode, J. E., 1975: Importance of irrigation timing and time and rate of nitrogen application for economic apple production. Compact Fruit Tree 8, 77-84.

Izumi, H., A. E. Watada, and W. Douglas, 1996: Optimum $\mathrm{O}_{2}$ and $\mathrm{CO}_{2}$ atmosphere for storing broccoli florets at various temperatures. J. Amer. Soc. Hort. Sci. 121, 127-131.

Janick, J., (ed). 2003: Wild Apple and Fruit Trees of Central Asia. Horticultural reviews, Vol. 29. John Wiley and Sons, Hoboken, NJ.

Janisiewicz, W. J., and D. Peterson, 2004: Susceptibility of stem pull area of mechanically harvested apples to blue mold decay and its control with a biocontrol agent. Plant Dis. 88, 662-664.
Janisiewicz, W. J., R. A. Saftner, W. S. Conway, and P. F. Forsline, 2008: Preliminary evaluation of apple germplasm from Kazakhstan for resistance to postharvest blue mold in fruit caused by Penicillium expansum. HortScience 43, 420-426.

Jones, A. L., and H. S. Aldwinckle, 1991: Bitter rot. In: Compendium of Apple and Pear Diseases, 15-16. APS Press, St. Paul, MN.

Juniper, B. E., R. Watkins, and S. H. Harris, 1999: The origin of the apple. Acta Hort. 484, 27-33.

Kidd,F., and C. West, 1924: The course of respiratory activity throughout the life of an apple. Annual report of the food investigations board, London. pp. 27-32.

Knee, M., 1993: Pome fruits. In: G. B. Seymour, J. E. Taylor, and G. A. Tucker (eds), Biochemistry of Fruit Ripening, 325-346. Chapman and Hall, London.

Lotter, L. D., V. Beukes, and H. W. Weber, 1985: Growth and quality of apples as affected by different irrigation treatments. J. Hortic. Sci. 60, $181-192$.

Mitcham, B., and A. Kader, 1996: Methods for determining quality of fresh commodities. Univ. Calif. Perishable Handling Nwslt. 85.

Morgan, J., and A. Richards, 1993: The Book of Apples. Ebury Press, London, U.K.

Ponomarenko, V., 1987: History of Malus domestica Borkh., origin and evolution. Bot. J. USSR. 176, 10-18. (in Russian).

Ponomarenko, V., 1992: Critical review of the system of the genus Malus Mill. (Rosaceae) species. In: Bulletin of Applied Botany, Genetics and Plant Breeding. Russian Acad. Agric. Sci. 146, $1-10$.

Prusky, D., J. L. McEvoy, B. Leverentz, and W. S. Conway, 2001: Local modulation of host $\mathrm{pH}$ by Colletotrichum acutatum as a mechanism to increase virulence. Mol. Plant-Microbe Interact. 14, $1105-1113$

Prusky, D., J. L. McEvoy, R. A. Saftner, W. S. Conway, and R. Jones, 2004: Relationship between host acidification and virulence of Penicillium spp. on apple and citrus fruit. Phytopathology 94, $44-51$.

Rosenberger, D. A., 1997: Recent research and changing options for controlling postharvest decays of apples. Proc. Harvesting, Handling, and Storage Workshop. Northeast Reg. Agric. Eng. Serv. Publ. NRAES-112. 14 August 1997. Cornell University, Ithaca, NY.

Seng, J. M., P. Saindrenan, and G. Bompeix, 1985: Induction of Nectria galligena mutants resistant to benzoic acid and study of their aggressiveness towards immature apples. J. Gen. Microbiol. 131, $1863-1866$.

Sharples, R. O., 1973: Orchard and climactic factors. In: J. C. Fidler, B. G. Wilkinson, K. L. Edney, and R. O. Sharples (eds), The Biology of Apple and Pear Storage, 173-225. Commonwealth Agricultural Bureau, Maidstone, Kent, UK.

Smith, R. B., E. C. Lougheed, E. W. Franklin, and I. McMillian, 1979: The starch-iodine test for determining stage of maturation in apples. Can. J. Plant Sci. 59, 725-735.

Spotts, R. S., L. A. Cervantes, and E. Mielke, 1999: Variability in postharvest decay among apple cultivars. Plant Dis. 83, $1051-1054$.

Struble, F. B., and G. Keitt, 1950: Variability in inheritance in Glomerella cingulata (Stonem.) S. and V.S. from apple. Am. J. Bot. 37, $563-576$.

Way, R. D., H. S. Aldwinckle, R. C. Lamb, A. Rejman, S. Sansavini, T. Shen, R. Watkins, M. N. Westwood, and Y. Yoshida, 1990: Apples. (Malus). In: J. N. Moore, and J. R. Ballington Jr (eds), Genetic Resources of Temperate Fruit and Nut Crops, 3-62. ISHS, Leuven, Belgium. Acta Hort 290.

Yao, C., W. S. Conway, and C. E. Sams, 1996: Purification and characterization of a polygalacturonase produced by Penicillium expansum in apple fruit. Phytopathology 86, 1160-1166. 